\title{
SUSTAINABLE DEVELOPMENT AND THE FUTURE GENERATIONS
}

Kemi Anthony Emina $\varangle$; Department of Religious Studies and Philosophy, Delta State University, Abraka, Delta State, Nigeria.

\begin{abstract}
Due to the increasing rate of human's economic activity and rapid population growth, twenty first century has seen an unprecedented environmental change. These changes have an unprecedented impact on climate, life-sustaining systems on the earth. Future generations are exposed to great harm by the way in which humans exploit environmental resources of the earth. There is a call among environmental ethicists to review human ethical relationship with the environm ent as to attain sustainable development for the now and the future generations. Hence, the essence of this paper is to discuss the anthropoholistic environmental ethics, sustainable development and the future Generations. This paper argues that humans nee $d$ to strive for a new and more respectful relationship with the natural environment in other to attain sustainable development. Also, human obligations towards sustainable development for the future must find a firm basis in social ethics: those obligatios have to do with our conception of a just society.
\end{abstract}

Keywords: Environnemental Ethics, Environnent, Sustainability, Future Generations .

eminakemi@yahoo.com

Citation: Emina, K. A. (2021). Sustainable development and the future generations. Social Sciences, Humanities and Education Journal (SHE Journal) $\quad, \quad 2(1), 57$ - 71. DOI: $10.25273 /$ she.v2i1.8611

\section{(c) BY-NC-SA}

Published by Universitas PGRI Madiun. This work is licensed under the Creative Commons AttributionNonCommercial-ShareAlike 4.0 International License. 


\section{INTRODUCTION}

Environmental ethics is one of the most important modern environmental conservation and sustainable development tools (Bassey et al., 2020). However, lot of persons in both underdeveloped and developed countries are not aware of its importance. It is vital for everyone to be ethically responsible towards the environment as to attain sustainable development for now as well as future generations. This is the only way forward to save our environment and planet from further degradation. Environmental ethics is interlinked with sustainable environment and development as a whole. It teaches us to be healthy and reciprocal to global environment and development. This virtue is basically based on international humanitarian law, international human rights, and international environmental law under public international law. Modern societies including the United Nations Organization (UNO) and its specialized agencies, International Union for Conservation of Nature (IUCN) and other national and regional organizations, etc., have been playing significant role in the process of implementing environmental ethics for human society in order to attain sustainable development. The compliance with the existing laws and policies along with environmental ethics are also crucial for human existence. It deals with environmental rights, moral education, traditional knowledge and environmental conservation issues, which are very important for sustainable development. The essence of this paper is to discuss environmental ethics, sustainable development and future generations.

\section{SUSTAINABLE DEVELOPMENT}

The World Commission for Environment and Development defined Sustainable Development as "development that meets the needs of the present without compromising the ability of future generations to meet their own needs" (1987, p.8). Also, the principle of sustainable development says that the pursuit of quality of life must be compatible with a similar equality of life for all including future generation (Boonchai \& Beeton, 2016). Such a principle seems to protect the future of environment. Paul Hawken in The Ecology of Commerce defined sustainability as follows:

\begin{abstract}
"Sustainability is an economic state where the demands placed upon the environment by people and commerce can be met without reducing the capacity of the environment to provide for future generations. It can also be expressed in the simple terms of an economic golden rule for the restorative economy: Leave the world better than you found it, take no more than you need, try not to harm life or the environment, make amends if you do" (Hawken, 1993, p.139).
\end{abstract}

The term sustainable development contains two key concepts. Firstly, the concept of needs the vital need of the world's poor, to which (overriding) priority should be given, and the idea of limitations imposed by the state of technology and secondly, social organization on environment's ability "to meet present and future needs" (Dennis 2020). Sustainable development is commonly understood to require a balanced pursuit of three goods such as ecological health, social equity, and economic welfare. It is grounded on the ethical commitment to the well-being not only of present generation population but also the wellbeing and enhanced opportunities of future generation. Sustainable development is about ethics, because it calls on present people not only to consider the condition of the current impoverished population, but also the potential condition of future 
populations who are the responsibility of our production and consumption patterns.

Inherent in the definition of Sustainable development is the proposed responsibility of contemporary society for the quality of life for present populations, in addition to the preservation of resources, environment, other ingredients needed for future populations, and quality of life. This is an enormous and difficult job as it requires huge changes in thinking, policy, and basic assumptions about the economy for its full implementation. For our contemporary age, more scientifically cultured societies would have to contribute substantially through a wide range of assistance programmes to increase the wealth of poorer nations, to help them in developing the capability to provide the basic needs of their population. It means affording them with wide range of resources that support a good quality of life for future generations. One may ask why do we apply the sustainability framework? To respond to these question, concepts like rights, obligations, and interdependence must be introduced. Everyone on the Earth has a right to food, shelter, and clothing. Every one existing today have an obligation to future generations to provide them a functioning planet at least as in a good state as they received it. We all are interdependent upon present and future generations, but it is the present generation in the wealthier countries that control the fate of future (Schiffman, 2011, p.230). Through a better understanding of the ethics of sustainability, it becomes clearer that sustainability framework is not only an approach to address and solve many difficult problems. However, we may ask, why is it in fact the right approach, the right thing to do?

The world faces numerous political, economic, and social challenges that threaten to undermine the welfare of people all over. Sustainability provides just the type of approach which is needed to address these challenges and the ethics of sustainability gives sustainability legitimacy as a framework. The ethics of sustainability provides a clear sense of the principles that make sustainability more than just a simple problem-solving system, but make it an idea that is grounded in commonly understood ethical principles. In short, the ethics of sustainability provides a moral authority behind sustainability as a fair and equitable approach in making the world a better place (Wang, 2013). Sustainability is a human construct in which human use their environment for a range of objectives, including subsistence, commodity production and aesthetic pleasure (Obilor et al., 2018). These objectives have their basis in the desire to sustain human life, enhancement of standards of living, maintenance of culture and protection of environmental quality for generations to follow. The different objectives for the use of environmental resources lead to different expectations as to what is to be sustained and who is to have claims on environmental services.

Equity is an important aspect of this approach to sustainability (Rosen, 2012). Environmental view of sustainable development focuses on the stability of biological and physical systems. The emphasis here is on preserving the resilience and dynamic ability of such systems to adapt to change, rather than conservation of some ideal static state. Natural resource degradation, pollution and loss of biodiversity reduce system resilience. Reconciling these various concepts and implementing them as a means to achieve sustainable development is a challenging task, since all these above three elements of sustainable development must be given a balanced consideration.

Ethical approach on sustainable development emphasizes on protection of environment which is a major objective of sustainable development (Edet 2017; Aboh 2014). Economic 
development ultimately depends on the institutions that can protect and maintain environment's carrying capacity and resilience. The behaviour of humans in relation to their use of environment is critical to the design and implementations of effective environmental protection. It should be noted that ethics and rules are effective in modulating the interaction between humans and their environment and this must reflect both general principles and specific social and ecological context. Ecological context contains the structure of eco-systems in which humans live and work, as well as the particular functional properties of those ecosystems.

However, radical ecologists are of the view that ethical extensionism is inadequate because it is stuck in traditional ways of thinking that led to those environmental problems in the first place. Their opinion is that it is too human centered (Strong Anthropocentricism) (Bassey, 2019). Social ecology and deep ecology are of the view that environmental crisis lies in the dominant ideology of western societies (Bassey, 2019). Ecofeminism points to the link between social domination and the domination of the natural world. By mid 1970s feminists had raised the issue of whether patriarchal modes of thinking encouraged not only widespread inferior sing and colonizing of women but also people of color, animals and nature. Ecofeminism calls for radical overhaul of the prevailing philosophical perspective and ideology of Western society (Ling, 2014). This will be addressed extensively.

From the above discussion it can be said that thoughts on environmental ethics demonstrate that, ethics has an important role to play in ensuring sustainability in a contemporary society. However, ethics alone cannot be effective to deal with the major causes of pollution and these include poverty, rapid population growth, deforestation and wars among others. Ethical behaviour could inspire a collaborative culture of new thinking and unconventional ideas that push change in unexpected way. Degradation has reached an alarming stage that it is vital to create greater awareness of environmental problems. Hence it is crucial to see how we comprehend our relationship between our daily practices and thinking and sustainability of natural world. We can affirm that any deliberate attempt to reach a rational and enduring state of equilibrium by planned measures, rather than by chance or catastrophe must ultimately be founded on the basic change of values and goals at individual, national and global level. Let us discuss some normative principles in sustainable development.

\section{SUSTAINABLE DEVELOPMENT AND ANTHROPOCENTRISM}

Environmental ethics is a field of study that tries to guide the conduct as well as review the relationship between man and the environment. There are two basic theories in environmental ethics i.e. anthropocentricism and nonanthropocentrism. Anthropocentrists emphasizes upon human centrality because humans are the only species who are intrinsically valuable and moral standing, while every other being in the environment are for human benefit. This worldview considers human's interest first before others in decision making. It has been argued by many philosophers that anthropocentric thinking and attitude is behind environmental degradation. This is because human over exploitation on the environment is due man strong desire to meet human's trivial needs. While on the other hand, non- anthropocentrists claim that other living things as well as nature are intrinsically valuable, hence man should show some form of respect to nature and other beings in the environment (Bassey \& Pimaro Jr, 2019). 
Sustainable development presupposes that "development that meets the needs of the present without compromising the ability of future generations to meet their own basic needs" (World Commission on Environment and Development, 1987, p.8). The Brudtland Report foresees a new era of economic growth and believes that such a growth is absolutely essential for the relief of poverty. On the other hand, it also believes that growth is not sufficient to relieve poverty and sees the need for new development path, which will sustain environmental capacity. Thus the approach seems to be anthropocentric as it aims at the benefit for humanity. However, there are two versions of anthropocentrism which must be distinguished- strong and weak anthropocentrism. Strong anthropocentrism presupposes the despot like attitude human beings towards nature, while weak anthropocentrism considers environmental values remaining within the anthropocentric purview (Bassey, 2019). This implies that weak anthropocentricism acknowledges human centrality it also accord some respect for other beings within the environment. Therefore, we can say that weak anthropocentrism supports some of the principles and objectives of sustainable development as defined by both the World Commission on Environment and Development and the Brudtland Report. Weak anthropocentric attitude supports environmental values, and sustainable development also supports the priority of the needs of present and future generations and the carrying capacity of ecosystems and restorative ability of environment.

\section{SUSTAINABLE DEVELOPMENT AND NON-ANTHROPOCENTRISM}

Non-anthropocentrism is the opposite of anthropocentrism as it does not emphasizes upon human centrality because humans are not the only species who are intrinsically valuable and moral standing in the environment. There are two varieties of nonanthropocentrism i.e. biocentrism and ecocentrism. Let us make a comparison between the two varieties of nonanthropocentrism with sustainable development. Biocentrism avers that that human being's attitude towards nature must be evaluated on the basis of how they affect living beings including humans and other individual species. According to biocentrists, apart from human individuals other individual organisms are under the moral purview (Sterba, 2012). Ecocentrism views is that people's attitude towards nature should be evaluated on the basis of how they affect species, the whole ecosystem, but not merely individual living beings. It is true that various versions of environmental ethical theories disagree about which natural things have intrinsic values (Washington et al, 2017). However we have to gather more information, whether these theories support the principle of sustainable development.

The theories, which give importance to human beings than other living things, will be much closer to weak anthropocentrism when it comes under the concept of sustainable development and environmental policies. The presupposition given by a weak anthropocentist is explicitly stated in the World Commission's book Our Common Future and the United Nation's Agenda 21. Similar documents expressing the presuppositions of biocentrism and ecocentrism are harder to find. In the Rio Conference it has been declared that human beings are at the center of concern for sustainable development. Thus the goal of weak anthropocentrism in the context of sustainable development is to ensure that natural resources are to subserve the purpose of humans in an 
efficient and farsighted way so that the needs of the present and future human generation can be satisfied (Stenmark, 2002). i.e. to create an ecologically sustainable situation.

If we compare sustainable development and biocentrism, we can get a good hint in Tom Regan, who explicitly states that the overarching goal of wild-life management should ensure maximum sustainable yield; it should be to protect the wild animals from those who would violate their rights (Regan, 1983, 357). It goes against the declaration of World Commission that it is not merely the well-being of humans, but also the interest of animals and ecosystems, which is the ultimate goal of sustainable development and environmental development policies. Thus the goal of biocentrism from the perspective of sustainability is, to ensure that humans in their treatment of nature need not violate the rights of other living things and they are to be left alone and to flourish (Regan, 1983, 357).

Ecocentrism from the
perspective of
development ensures that humans in their approach towards nature need not violate the integrity and stability of the biotic community and its individual members (Washington et al, 2017). When we make sustainable policy making, we must consider the health and flourishment of species, ecosystem, wetlands, rain forests and endangered species and think that they are at the heart of concern whether or not they benefit the human community. Some issue must be cited here that the goals for sustainability and environmental policy making envisioned by anthropocentrists and nonanthropocentrists are not the same. Rather both the approaches support divergent policies to such an important extent that we become aware that what should be the goal of environmental protection and sustainable development. The value commitments in both the theory are different and they generate divergent policies for attaining sustainable development.

\section{FUTURE GENERATION}

The World Commission on Environment and Development defines Sustainable development as "development that meets the needs of the present without compromising the ability of future generations to meet their own needs" (Cowell, 1996, 508). This principle says that the pursuit of quality of life must be compatible with a similar equality of life for all including future generation. Such a principle seems to protect future generation and environment. Thus, according to this principle, we have a duty to conserve the resource of nature because they are essential to all human life both at present and in the indefinite future. Here the moral significance falls on our responsibilities to other species and to nature in itself, and more on the duties we have towards it in virtue of the obligations we have towards future generations.

Our thoughts and talk are replete with reference to the future, with reference to "what will be". We think that we can in fact change and affect the future, and we act accordingly. So we may say that our actions have a direction towards future. Our present actions have bearing on especially future people, people we have no chance of meeting in our lifetime. This is something we are increasingly realizing, with the degradation of the environment starring right at our face as a constant warning about the world that we about leaving behind us. Our present actions, decisions may not only have bearing on the wellbeing of future generation, but also determine whether future generation would exist at all.

There raises two more fundamental questions, when we 
discuss about future generation. Firstly, what do we mean by future, or to be more precise future people? The reason why this needs to be clarified is that it seems in a way that we who presently exist should be morally bound to the beings that do not exist now and may not even ever exist, people who have no reciprocal moral relation with us. We understand how confusing the phrase 'future people' is as soon as we realise that future persons may mean so many things. Our understanding may be expressed in the following way.

- A baby who is to born tomorrow is a future person.

- A baby yet to be conceived but is very much likely to be conceived is a future person.

- A generation to born constitutes future generation. Even we may think of generations which might possibly exist centuries ahead of ours and so on.

Secondly, why do people think about future? In the end we cannot but think about the future. It is an existential burden for all of us to carry, some more constructively than others. The great psychologist Abraham Maslow said that thinking about future and planning for future are central attributes of a healthy human personality (Cocks, 2003, 135).

At a practical level, people think about future because they want future to be kind to them or to others, such as their grandchildren; and planning for future thoughtfully choosing today's actions with regard to their future consequences may help that to happen. Even when it appears that one's future situation cannot be influenced by today's actions, it may still be judged useful to plan responses to the occurrence of any of various scenarios of possible futures. People also think about aspects of future in a disinterested way, that is, without interpreting what might unfold in terms of their own self-interest. This sort of thinking may just be curiosity driven or it may stem from a concern for others, for society if we prefer. We may say that we have to review our ethical stand in view of the following questions about future generation.

- Do we have obligation to future generation at all?

- Which ethical theory should govern our assessment of future events?

- Should the ethical approach towards future generation be egalitarian or utilitarian?

One may also say that the issue of obligation towards future generations raises two more interesting questions (Stephen, 1991). The first question is concerned with the identity of future generations and this is usually center on the identity of future persons based on specific genetic criteria, i.e. they are persons linked to us genetically and form specific link between us and future people. However, one may not find any definition of identity dealing with the problem in light of the problem of identity over time. The question remains, what constitutes a link between ourselves and those to whom we supposedly have an obligation?

The second question is concerned with the possibility of perceiving future obligations as obligations to all future generations taken as a group, without any specific identity of the individuals in that group. Even if we do not know precisely who it will be, someone will live in generations after us. But moral obligations are usually undertaken in reference to one's own promises or commitments to specific individuals. It is unclear what type of obligation exists with reference to a group of people to whom no promises have been made.

\section{Moral Status of Future Generation}

Moral status is a characteristic that we human moral agents attribute to entities, regardless of whether other 
beings are concerned about them. When an entity has moral status, we owe some moral obligations to that entity itself. As a moral agent, we need to care to some degree about what it wants or needs, or simply what it is. This imposes some limitations on how we may act towards it. Moral status of future generation may involve nothing more than a simple extension of our moral community to include family, animals, ecosystems and persons who will born after we have departed. By this account, our responsibilities to future generation would not be significantly different in kind from our responsibilities to present generations. It seems that given our knowledge and capacities, future persons have a right to our responsible care and forbearance on behalf of them. However, if we have a closer look, it can be revealed that the ontological and epistemological status of future persons rises numerous and extraordinary moral and meta-ethical problems. Let us discuss some of them (Clowney \& Mosto, 2009, p. 639).

- Most fundamentally, future persons, qua future, do not exist now, when the alleged burdens of responsibility fall upon the living. Thus, question may be raised that can we have duties to nonexistent beings? What sense can be made of attributing rights to those who do not exist?

- The more perplexing fact is that by initiating a policy to improve the lives of future persons, we will be causing different individuals to be born in future. But if so, then we can in no sense be said to be 'improving the lives' of particular future persons, who, but for our provision would not exist. We cannot know future people as individuals. Also, 'posterity' is an abstract category containing unnumbered and undifferentiated members. And yet, much moral concept is based upon the principle of "respect for autonomous individuals."
- Our relationship with future generations is unidirectional and nonreciprocal. Future individuals will be unable to reward or punish us, as the case may be, for our provision for their lives.

- How can we tell with any confidence just what might benefit future persons i.e., what will or will not be 'good' to them?

- Who is entitled to act on behalf of future persons?

Thus, assigning moral significance to those not yet born, we are introducing and inviting problems that are unique to the history of moral philosophy. But we cannot extend our moral concern towards them as we do in the moral status of non-human species. All these questions are related to a more basic question, which makes ethics of posterity at the same time so difficult and so interesting like, what is the metaphysical as well as ethical status of future people?

When we say that something counts morally in its own right, it means we are thinking of its intrinsic worth or value rather than its instrumental value. For example, if it were morally right to treat animals well only because this would promote kindness between persons, then animals would count morally. That is, they should be treated well not because of what they are in their own right, but because of the effects on others of treating them well. That is, if the animal counts morally in its own right, there is no further end that needs to be served by our treating animals well in order for us to have a reason to treat it well. When we save a bird, we can do it for the bird's sake, because it will get something out of its continued existence and it could be harmed if it does not continue to exist. This is because an entity must be able to get something out of its continuing existence and a capacity for consciousness seems to be necessary 
for this.

We can say that an entity has moral status when in its own right, for its own sake, it gives us reason to help it and to refrain from destroying it. On this account, a nonsentient, nonconscious embryo lacks moral status but could count morally in itself (for example, could give us reason in its own right not to destroy it) because of its intrinsic and extrinsic properties, such as what its potential is. This is different from merely having instrumental value because it will give rise to a future person that has moral status. In case of future generations we can say that they count morally in itself because of their intrinsic and extrinsic properties, such as what their potentialities are.

In his essay, Norman Care presents doubts regarding "our ability to solve the motivation problem relative to what morality requires on behalf of future generations" (Care, 1982, p.195). He argues that (a) we can have no bonds of love or concern for indefinite future persons: "their interests cannot interest us;" (b) we have no "community bond" with future persons no "sense of belonging to some joint enterprise;" and finally, (c) we feel no "extended or unbounded sharedfate motivation," no "sense of common humanity". This proposal immediately suggests two problems: first, it implies that childless individuals are incapable of caring for future generations, and thus are excused from making just provision (Care, 1982, p.195).

\section{ANTHROPOHOLISM AND THE OBLIGATIONS TOWARDS FUTURE GENERATION}

Obligations towards future generations examine moral issues concerning persons and other beings who have yet to born, but may come into existence. The questions it examines include whether future persons are morally significant, whether they have a right to exist, whether we are required to make certain sacrifices for the sake of their welfare, whether concern for future persons can abrogate moral obligations to existing persons, and what sorts of resources and institutions we are obligated to pass to them. Philosophical concerns for future generation go back to at least Aristotle's theory of distributive justice (Knoll, 2016). In contemporary literature, obligations to future generations are often included within discussions on intergenerational justice, which concerns moral obligations, that presently existing moral agents owe to noncontemporaneous past and future generations, in part because of Rawls advocating its inclusion within the domains of justice. Why do present generations have an obligation towards future generation? Present generation has obligations towards future generations because there remains a kinship relationship between the present generation and the future generations. It is a biological fact that future generation would be causally linked with present generation. It is an attempt to extend notions of obligations of justice from those that apply to current existing persons and groups to those that apply over time. Human being's actions affect natural system. We humans among all living creatures have the capacity to shape our relationship to environment. We can use it on a sustainable basis or we can degrade environmental quality and natural resource base. As part of the natural system, we have no right to abolish its integrity; nor is it in our interest to do so. Rather, as the most sentient of living beings, we have a special responsibility to care for the planet.

In recent years, lawyers have begun to join with the ecologists in debating whether there should be obligations to protect the interests of future generations (Gündling, 1990, 208). This legal debate was preceded 
by a philosophical one, in the early 1970 s, on the emergence of a new or "ecological ethics" redefining the relationship between man and nature in such a way as to ensure the survival of human species on Earth (Gündling, 1990). The background of the various ethical approaches has been an indisputable fact that humanity has accumulated a monstrous potential to destroy life on Earth, and that it is using natural resources and environment in a way that threatens the survival of future generations at a standard that we today consider worthy of human beings. According to some law makers our responsibility towards future generations not only as a moral postulate, but also as a legal principle. The protection of future generations is mentioned specifically in various international instruments (Gündling, 1990). Also responsibility towards future generations is an implied subject of several recent developments. Our duties towards protecting future generations can be disputed and need to be justified. Duties towards future generations or rights of future generations ultimately rest on a value judgment. This is a fundamental assumption which reveals the fact that human species and all other species, should survive, and that future generations are entitled to live in dignity.

We cannot simply rely on the assumption that our way of dealing with nature and environment will turn out to be harmless. Nor can we expect that future generations will develop knowledge and technology which is necessary to cope with all the problems they inherit from us. Therefore, at present we need to take necessary preventive measures, or more precisely, precautionary action, which will ensure that natural resources are used sparingly and that degradation of environment is reduced to a minimum. This, will be achieved only if we change our basic system and thinking about values. We need to understand that economic growth is not an indicator of progress, nor is wealth necessarily an indicator of prosperity. Environmental problems we face now show that the growth of our technological power calls for a new, more forward-looking notion of moral responsibility, which is helpless to trace and anticipate the farreaching consequences of our present actions. One may ask, "But we don't know what people in the future will want," "May be they will prefer a world of fast roads and vast shopping malls, and a world of luxury. So why preserve things for them that they may not even appreciate?" This is the argument from ignorance. In standard form it goes something like this:

* We can have obligations to beings only if we can know what those beings are like and what they need or desire, and

* We can't know what future people will be like or what they will need or desire. Therefore, we have no obligations to future people.

The argument is valid. And the first premise is probably accurate; if we knew absolutely nothing about a class of beings, then we could not know what was good or bad for them and would have no basis on which to act responsibly toward them. Our ignorance, moreover, would not be willful, since the first premise envisions a situation in which no information about these beings is available to us. But the second premise is false. We have a great deal of inductive evidence, based on the entire past history of humanity and on its biology, physiology and psychology, for what future people will be like and what they will need or desire. We can be virtually certain, for example at least with respect to people living in the next few centuries that they will need sources of food, clothing, shelter, and clean water and air. They will prefer an environment that is not dangerously contaminated with toxic or radioactive substances. It is very 
likely, given what we know of humans so far, that many of them will want open space and natural beauty. Clearly we know enough to act with some degree of responsibility towards future people. We may not hide behind the excuse of ignorance and there is a further point: we are to a certain extent responsible for shaping what future generations will want, not only in the way we educate people, but also in our shaping of the world. If we destroy wilderness, for example, then we ensure that future generations will never value wilderness; for how could they learn to love what they will never know? If, by contrast, we preserve wilderness, then we preserve at least the possibility of their valuing it. And, given the pervasive human appreciation of nature across history and culture, it is likely that many future people will realize that possibility. Thus, we know what future generations will need, not only because we know what human beings in general want, but also because to some extent we participate in shaping their values.

\section{SUSTAINABLE DEVELOPMENT, ENVIRONMENTAL PLANNING AND MANAGEMENT}

To attain 'sustainable development' environmental planning and management is very necessary. Planning should be directed towards

(i) An overall growth of the society and (ii) Removal of socio-economic disparities through proper utilization of resources. Environmental management which is related to rational adjustment based on the principle of realization between man and nature involving judicious exploitation and utilization of natural resources without disturbing the ecological balance and ecosystem equilibrium is the need of the day. Environment management aims at improvement of human-environment relationship by imposing a check on destructive human activities, along with conservation, protection, regulation and regeneration of nature. Such management is sure to bring out socio-economic development on one hand and improvement of environmental quality on the other. There are two approaches in environmental planning and management such as, the preservative approach and the conservative approach. First, the preservative approach promotes non-interference of human with nature and total adaptation of human to nature, i.e. human must surrender completely to the whims of nature. This approach is not practicable as it would lead to the total extinction of human. Second, the Conservative approach is in fact practicable as it advocates humanenvironment adjustment in terms of judicious utilization of natural resources for socio-economic development and at the same time maintenance of ecological balance, ecosystem, stability and environmental quality by adoption of eco-friendly and pollution free technologies.

One may say that environmental planning and management needs to be based on the following ecological principles in order to attain sustainable development:

(i) The biotic and abiotic components of the environment are interrelated which in turn are related to large scale biogeochemical cycles.

(ii) Sustained life on Earth is a characteristic of eco-system.

(iii) Resources of the planet are mostly finite.

(iv) Resources are created over millions of years.

(v) All living species and the physical environment are mutually reactive.

(vi) Energy flow in the eco-system is governed by the first and the second law of thermodynamics. 
(vii) Productivity of the eco-systems depends on the availability of solar energy and the ability of the plants to transform solar energy into chemical energy.

Environmental planning and management based on the above mentioned ecological principles will foster harmonious living of all species within an ecologically balanced environment. The question arises that how sustainable development should proceed? Restoration of environmentally degraded areas along with launching of new development projects in previously developed areas incurs large expenditure and at the same time may not be successful. Such development strategy cannot be called sustainable. In an eco-systemic sense sustainability of both eco-system and human life requires development. Therefore, in order to understand sustainability or carry out sustainable development in the eco-systemic sense, the good of all non-human entities needs to be recognized along with the good of human beings. Once it is recognized conditions favouring or assuring the good of all entities should be stably maintained. Thus human actions needs to be directed not only towards maintenance of human wellbeing or human good but also towards promotion of good or well-being of all non- human entities constituting the eco-systems and therefore the environment. Such an endeavour would be sustainable development of the society in the true sense of the term.

The question which arises is whether sustainable development can be achieved in its true sense without taking environmental justice into consideration? In fact, sustainability, development and environmental justice are all interconnected or interlinked and the discussion of one by forfeiting the other makes our understanding incomplete. We all know that the environment is our habitat and we are all the constituents as well as the observers of the environment. We are therefore entitled to a healthy and protective life in harmony with nature. All biotic species indeed are entitled to acquire proper or qualitative living within a healthy environment. These entitlements involve duties or obligations on the part of international or national organization, governments of different countries with the aim to meet equitably the development and environmental needs of the present and future generations. The question of justice comes only when the desire and needs of human exceeds the means of satisfaction. Justice may usually be applied in areas of scarcity of resources. The scarce resource needs to be distributed equitably among the members residing in that area so that each gets their fair share. But it is even wrong to think that justice is not required when resources are plentiful. To allow people to utilize plentiful resources according to their desire will eventually jeopardize the environment. We understand that we do require development, which can come through science and technology, but such development must protect the generative capacity of nature, natural environment in the true sense of the term. If any of such development would be detrimental to the natural environment, degrade the so-called biosphere, transform the fertility of natural environment to barren land, such type of development must be resisted. So when we plead for environmental development through sustainability, we must resist the socalled modern scientific development based on consumerism, materialism, individual subjectivism where ups and downs, exploitation and subjugation, where superiority and inferiority in terms of material wealth is the sole criterion of cultural development, where development runs with empty ethical foundation, metaphysical basis. Such type of development is no longer sustainable. So sustainability is the 
criterion of development. However, when we talk about sustainable development, we thereby rationalize ourselves, set a rational criterion of development which is associated with morality, ethics and metaphysics and it will rationalize human's desires. So it can be said that sustainable development in one sense is very much a form of enlightened anthropocentrism or popularly known as weak anthropocentrism, but it would require a different attitude of humans which is unlikely in the domain of strong anthropocentrism. Environmental ethics in the form of non-anthropocentrism actually has tried to bring back humans attitude towards nature in a revolutionary manner. It tries to show or at least it gives opportunity to humans to re-look their own position through the realization process where they stand, what they are doing, what is wrong with them, and how they overcome the harmful actions that give rise to serious threat to the mankind in general.

We think that sustainability is not a pure form of nonanthropocentrism, but definitely it is an enlightened from of anthropocentrism and shallow ecological attitude by means of which environmental journey has started. There is no question of doubt that sustainability requires a drastic change of humans' attitude towards nature which is completely foreign in the domain of brute anthropocentrism. Sustainable development is intimately associated with environmental justice, because sustainable development can only be restored through the process of environmental justice. We should not abuse our natural resources and we should preserve our natural resources for future generations.

\section{CONCLUSION}

Since the 1970s, the topic of ethical obligations to future generations has been of interest to philosophers, economists, environmentalists, and others. While the context for application differs for each field, the central issues are the same: whether a current generation has moral obligations to non-contemporaneous future generations, the nature of those obligations, and whether those obligations require an earlier generation to make sacrifices for a future generation. For example, does the present generation have the right to exhaust the planet's resources or render the planet uninhabitable? Do future generations have rights which require the present generation to conserve resources and preserve the environment for future generations? All thoughtful people agree that we ought not to make the world a much less pleasant place for our descendants than the world we have inherited from our ancestor by dumping our wastes into rivers, lakes and oceans, cutting down our forests indiscriminately, and polluting the atmosphere with noxius gases. As temporary inhabitants of this planet, we do have certain duties to perform for future generations such as not to pollute the atmosphere, to protect threatened plant and animal species, to preserve the beauty of the wilderness areas, and artistic treasures of earlier human civilization. These are certain valuable objects, and things what we have inherited from our ancestors, and we must preserve them for our descendants. If we talk about the duties to future generation, we imply that future generations have rights, which are morally obligated to respect. Joel Feinberg, on The Rights of Animals and Unborn Generations, emphasizes the interests of future generations to preserve endangered species. He says, "surely we owe it to future generations to pass on a world that is not a used up garbage heap" (Feinberg, 1994, p.434). We as temporary inhabitants of this planet, therefore, have certain duties to 
perform for future human beings to leave a livable planet. Finally, it can be concluded that sustainable development is constructed in a way that it reflects how society wants to live in nature, about the expectations of society for the future, and the societal idea of justice. The construction is taking place in the presence of power. Thus, the concept sustainable development needs to be reflected philosophically and politically when used.

\section{REFERENCES}

Aboh, J. A. (2014). Conflict management: A panacea to development. Sophia: An African Journal of Philosophy, 14(2), 64-67.

Bassey, S. A. 2019). 'Anthropoholism'As an Authentic Tool for Environmental Management. International Journal of Environmental Pollution and Environmental Modelling, 160-168.

Bassey, S. A., \& Pimaro Jr, T. M. (2019). Enyimba's Notion of Madukaku and The Question of Anthropocentricism In African Environmental Ethics.

Bassey, S. A., Orji, M. O., \& Afolabi, O. (2020). An Overview of Materialistic and Unified approach to Man - Nature Relationship. GNOSI: $\quad A n$ Interdisciplinary Journal of Human Theory and Praxis, 3(3), 17-28.

Boonchai, C., \& Beeton, R. J. S. (2016). Sustainable Development in the Asian Century: An Inquiry of Its Understanding in Phuket, Thailand. Sustainable Development, 24(2), 109-123. https://doi.org/10.1002/sd.161 $\underline{2}$

Care, N. (1982). "Future Generations, Public Policy, and the Motivation Problem," Environmental Ethics, Fall, p. 195.
Clowney, D., \& Mosto, P. (2009). Earthcare: An Anthology in Environmental Ethics, Rowman \& Littlefield Publishers, Inc. p.639.

Cocks D. (2003). Deep Futures: Our Prospects for Survival McGillQueen University Press, p. 135.

Cowell, C. (1996). Community Nutrition in Action: An Entrepreneurial Approach. TOPICS IN CLINICAL NUTRITION, $11(3), \quad 86$. https://doi.org/10.1097/00008 486-199606000-00011

Dennis, O. (2020). Ethics of Posterity for Environmental Development of the Niger Delta. GNOSI: An Interdisciplinary Journal of Human Theory and Praxis, 3(3), 83-96.

Edet, A. (2017). Security Agents In Nigeria Sea Ports: A Focus On Port Harcourt Sea Port. Global Journal of Applied, Management And Social Sciences, 13

Eyo, U. E. (2019). Between Religion and Agriculture: A Roadmap to Revamping Nigeria's Economy. GNOSI: $\quad A n$ Interdisciplinary Journal of Human Theory and Praxis, 2(1), 62-70.

Feinberg, J. (1994). "The Rights of Animals and Unborn Generations", in James E. White, (edit), "Contemporary Moral Problems", New York, West Publishing Company, p. 434.

Gündling L. (1990). Our Responsibility to Future Generations The American Journal of International Law, Vol. 84, No. 1, p. 207-212

Hawken, P. (1993). The Ecology of Commerce: a Declaration of Sustainability, Harper-Business, A Dvision of HarperCollins Publishers. p.139

Knoll, M. A. (2016). The Meaning of Distributive Justice for Aristotle's Theory of Constitutions. ПНГН/FONS, $1(1)$. 
https://doi.org/10.20318/fons.2 016.2529

Ling, C. (2014). Ecological Criticism Based on Social Gender: The Basic Principles of Ecofeminism. Higher Education of Social Science, $\quad 7(1), \quad 67-72$. https://doi.org/10.3968/4895

Obilor, O. I., Kenneth, I., Okoroafor, F. O., Chima, E., \& Bello, M. B. (2018). Democracy and National Development: A Focus on Nigeria. GNOSI: $\quad A n$ Interdisciplinary Journal of Human Theory and Praxis, 1(2), 1-8.

Regan, T. (1983).The Case For Animal Rights, Berkley: University of California Press, p. 357.

Rosen, M. A. (2012). Engineering sustainability: A technical approach to sustainability. Sustainability, 4(9), 2270-2292. https://doi.org/10.3390/su409 $\underline{2270}$

Schiffman, H. S. (2011). Green Issues and Debates: An A-to-Z Guide, Sage Publications Ltd., p.230.

Stenmark, M. (2002). 'The relevance of environmental ethical theories in policymaking' Environmental Ethics, 24:2, p. 137.

Stephen M. C. (1991). 'The problem of future generations: as it relates to environmental ethics,' Journal of the Evangelical Philosophical Society, 14:1.

Sterba, J. P. (2012). Biocentrism. In Encyclopedia of Applied Ethics (pp. 251-257). https://doi.org/10.1016/B9780-12-373932-2.00350-1

Wang, Y. (2013). From virtue ethics to virtuous corporation - putting virtues into business practice. Platform, 5(1), 131-139.

Washington, H., Taylor, B., Kopnina, H., Cryer, P., \& Piccolo, J. J. (2017). Why ecocentrism is the key pathway to sustainability (The Ecological Citizen). The Ecological Citizen, 1(1), 35-41.
Retrieved from https://www.ecologicalcitizen.n et/article.php?t=whyecocentrism-key-pathwaysustainability

World Commission on Environment and Development. (1987). Our Common Future (The Brundtland Report). In Medicine and War (Vol. $\underline{008808408783}$ 